ISSN : 2550-0198

\title{
PEMANFAATAN BARANG-BARANG BEKAS YANG BERNILAI EKONOMI BAGI PENINGKATAN \\ PRODUKTIVITAS JIWA ENTREPRENEUR IBU RUMAH \\ TANGGA RT.01/RW.12 DESA LIMBUNGAN KECAMATAN RUMBAI PESISIR
}

\author{
M.Fikry Hadi *, Ranti Darwin, Dwi Widiarsih, Muhammad Hidayat, Neng \\ Murialti, Mizan Asnawi \\ Prodi Ekonomi Pembangunan, Fakultas Ekonomi dan Bisnis \\ Universitas Muhammadiyah Riau \\ *Email: fikrihadi@umri.ac.id
}

\begin{abstract}
Abstrak
Perguruan tinggi sebagai lembaga pendidikan memiliki tugas pokok melaksanakan proses pendidikan dan pengajaran, serta melaksanakan penelitian dan pengabdian masyarakat. Pengabdian masyarakat adalah suatu gerakan proses pemberdayaan diri untuk kepentingan masyarakat. Adapun pelaksanaan kegiatan pengabdian dapat membawa perubahan kepada masyarakat yang lebih baik. Adapun bentuk pengabdian masyarakat yang dilakukan oleh Dosen Fakultas Ekonomi salah satunya adalah mengadakan pelatihan dengan memberikan keterampilan kepada ibu Rumah Tangga dalam bentuk pembuatan kreasi produk-produk bernilai ekonomis dari barang bekas. Setelah di adakan pelatihan diharapkan Ibu-ibu Rumah Tangga dapat mengembangkan variasi produk menjadi barang yang memiliki nilai jual tinggi dan menjadi entrepreneurship yang sukses.
\end{abstract}

Kata kunci : Entrepreneur, Barang Bekas, Peningkatan Produktivitas.

\section{PENDAHULUAN}

Dalam mencapai kondisi masyarakat yang hidup sehat dan sejahtera di masa yang akan datang, akan sangat diperlukan adanya lingkungan permukiman yang sehat. Dari aspek persampahan, maka kata sehat akan berarti sebagai kondisi yang akan dapat dicapai bila sampah dapat dikelola secara baik sehingga bersih dari lingkungan permukiman dimana manusia beraktifitas di dalamnya. Sampah merupakan konsekuensi langsung dari kehidupan, sehingga dikatakan sampah timbul sejak adanya kehidupan manusia. Timbulnya bersamaan dengan aktivitas manusia, mulai dari usaha pengambilan sumber daya alam sebagai bahan baku berlanjut menjadi bahan yang siap untuk energi, bahan setengah jadi untuk suatu barang dan aktivitas jasa dalam mengonsumsi barang-barang tersebut untuk mencapai kesejahteraan hidup manusia.

Sampah masih menjadi kendala di berbagai daerah, termasuk Kota Pekanbaru. Kenyataannya, produksi sampah berbanding lurus dengan perkembangan kota itu sendiri. Berbagai cara dilakukan pemerintah untuk dapat menghilangkan imej kotor di daerahnya.

Keberadaan sampah di kehidupan sehari-hari tak lepas dari tangan manusia yang membuang sampah 
ISSN : 2550-0198

sembarangan, mereka menganggap barang yang telah dipakai tidak memiliki kegunaan lagi dan membuang dengan seenaknya sendiri. Kurang kesadaran akan pentingnya kebersihan menjadi faktor yang paling dominan, di samping itu kepekaan masyarakat terhadap lingkungan harus dipertanyakan. Mereka tidak mengetahui bahaya apa yang akan terjadi apabila tidak dapat menjaga lingkungan sekitar. Dinas Kebersihan dan Pertamanan Kota Pekanbaru, Riau (2016), menyatakan wilayah tersebut saat ini mampu menghasilkan sampah 500 ton/hari, dari sekitar 1,3 juta penduduk. Secara rata-rata, 2,6 kilogram sampah diproduksi tiap penduduknya setiap hari.Dalam upaya penaggulangan sampah di Kota Pekanbaru ini, maka salah satunya dilakukan proses daur ulang. Daur ulang merupakan proses untuk mengurangi penggunaan bahan baku yang baru, mengurangi penggunaan energi,mengurangi polusi,kerusakan lahan,dan emisi gas rumah kaca jika dibandingkan dengan proses pembuatan barang baru.

Pada saat sekarang ini kegiatan daur ulang bisa dilakukan dengan memanfaatkan barang bekas menjadi yang sangat memiliki nilai ekonomis yang tinggi bahkan dalam proses pemasaran juga memiliki harga yang cukup tinggi.Selain diproduksi untuk pemasaran, dan menghasilkan uang,pemanfaatan barang bekas ini juga bisa digunakan sebagai media pembelajaran dan kreativitas semua kalangan, selain itu juga bisa membuka lapangan pekerjaan bagi masyarakat.

Pemanfaatan sampah daur ulang ini tentunya juga akan memberikan dampak positif untuk mendorong jiwa entrepreneur untuk terus dapat berkreatifitas dalam mengolah sampah anorganik ini menjadi produk-produk yang berkualitas. Produk-produk yang dihasilkan dari barang-barang bekas ini memiliki nilai jual yang bersaing dipasaran. Kegiatan ini tentunya akan mendorong tumbuh kembangnya sektor UKM di Kota Pekanbaru untuk menunjang perekonomian masyarakat.

\section{Rumusan Masalah}

Bagaimana cara meningkatkan nilai guna bahan-bahan bekas dan bagaimana cara memanfaatkan dan membuat bahan bekas menjadi barang yang bermanfaat.

\section{Tujuan}

Tujuan dari pengabdian masyarakat ini adalah : memberikan pengetahuan tentang menumbuh kembangkan jiwa kewirausahaan dan memanfaatkan barang-barang bekas yang memiliki nilai ekonomi.

\section{Manfaat}

Dengan dilaksanakannya pengabdian masyarakat ini maka diharapkan para ibu-ibu rumah tangga dapat mengembangkan kreativitas dan mendorong semangat entrepreneur untuk meningkatkan pengahailan tambahan bagi perekonomian keluarga.

\section{METODE PENGABDIAN}

Kegiatan ini tidak terlepas dari dukungan pihak terkait yang mendukung kelancaran pelaksanaan kegiatan pengabdian ini. Koordinasi dan komunikasi yang baik antara 
ISSN : 2550-0198

masyarakat yang akan menjadi peserta pengabdian dengan pelaksana kegiatan merupakan salah satu faktor penentu keberhasilan kegiatan pengabdian ini. Sebelum memulai kegiatan pengadian ini, tim pengabdian melakukan survey awal ke lokasi tempat pengabdian akan berlangsung dan berkoordinasi dengan perangkat daerah setempat.

Kegiatan pengabdian pada masyarakat di laksanakan dengan metode ceramah, demonstrasi/ pelatihan dan tanya jawab yang dilaksanakan selama 1 hari. Adapun tahapan-tahapan dalam pelaksanaan kegiatannya adalah sebagai berikut : Ceramah digunakan untuk penyampaikan pengetahuan secara umum tentang manfaat berwirausaha, peluang wirausaha. Demonstrasi digunakan untuk memberikan keterampilan secara langsung mengenai proses pembuatan produk dari barang-barang bekas kain perca, botol bekas, Koran bekas dan selongsong bekas dan penyiapan peralatan yang berkaitan dengan pembuatan produk.

Pelatihan pembuatan produk dari barang bekas ditujukan untuk memberikan pengetahuan kepada para ibu Rumah Tangga yang tidak bekerja namun ingin produktif untuk memiliki penghasilan tambahan. Evaluasi hasil pelatihan dilakukan selama proses dan setelah kegiatan pelatihan dilaksanakan.

Kamus Besar Bahasa Indonesia (2008) mengartikan sampah sebagai benda yang dibuang karena tidak terpakai dan tidak dapat digunakan lagi. Manik (2003) mendefenisikan smapah sebagai suatu benda yang tidak digunakan atau tidak dikehendaki dan harus dibuang, yang dihasilkan oleh kegiatan manusia. Sementara didalam UU No 18 Tahun 2008 tentang Pengelolaan Sampah, disebutkan sampah adalah sisa kegiatan sehari hari manusia atau proses alam yang berbentuk padat atau semi padat berupa zat organik atau anorganik bersifat dapat terurai atau tidak dapat terurai yang dianggap sudah tidak berguna lagi dan dibuang kelingkungan,(Slamet, 2002:15 ).

Schumpeter dalam As'ad (2002: 145) mengemukakan bahwa wirausaha atau entrepreneur adalah seseorang yang menggerakkan perekonomian masyarakat untuk maju ke depan, mencakup mereka yang mengambil risiko, mengkoordinasi penanaman modal atau sarana produksi, yang mengenalkan fungsi faktor produksi baru atau yang mempunyai respon kreatif dan inovatif. Clelland dalam As'ad (2002: 145) mendefinisikan wirausaha adalah orang yang menerapkan kemampuannya untuk mengatur, menguasai alat-alat produksi dan menghasilkan hasil yang berlebihan yang selanjutnya dijual atau ditukarkan dan memperoleh pendapatan dari usahanya tersebut.

Suryana (2009) juga berpendapat bahwa seorang wirausaha adalah mereka yang melakukan usaha-usaha kreatif dan inovatif dengan jalan mengembangkan ide dan meramu sumber daya untuk menemukan peluang dan perbaikan hidup. Wirausaha juga dapat didefinisikan sebagai orang yang memiliki, mengelola, dan melembagakan usahanya sendiri.

\section{HASIL DAN PEMBAHASAN}


Kegiatan pengabdian kepada masyarakat ini dilaksanakan di RT.01 / Rw.12 Desa Limbungan Kecamatan Rumbai Pesisir Kota Pekanbaru. Terlaksananya kegiatan ni sesuai dengan jadwal yang telah ditetapkan dan disepakati oleh ibu-ibu Rumah Tangga sebelum kegiatan ini dimulai. Pengabdian kepada masyarakat ini dimulai dengan melakukan tahap persiapan, pada tahap ini dilakukan observasi dan permohonan izin kepada perangkat desa RT.01 / Rw.12 Desa Limbungan Kecamatan Rumbai Pesisir sebagai tempat pelaksanaan pengabdian ini. Selain itu pada tahap persiapan juga mencari informasi jumlah peserta dan kegiatan peserta sebelum diadakan pelatihan kepada ibu-ibu di Desa Limbungan Kecamatan Rumbai Pesisir. Setelah waktu pelaksanaan disepakati, tim dari Dosen Fakultas Ekonomi dan Bisnis menyusun jadwal pelaksanaan dan membuat kesepakan dengan pihak perangkat desa dan ibu-ibu Rumah Tangga RT.01 / Rw.12 Desa Limbungan Kecamatan Rumbai Pesisir.

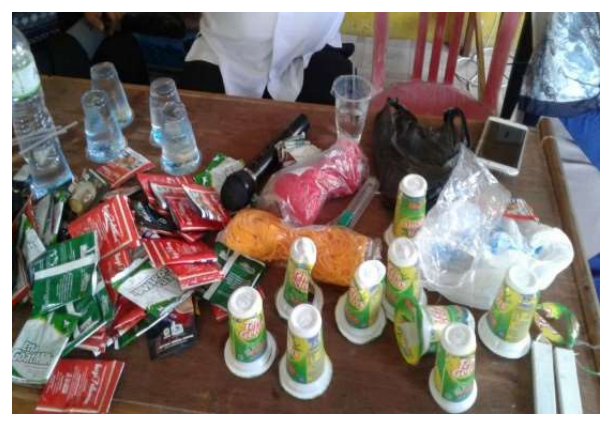

Gambar 1. Bahan-bahan dari barang bekas.

Adapun tujuan dari kegiatan pelatihan ini dilaksanakan dalam rangka pelaksanaan Catur Dharma Perguruan Tinggi Muhammadiyah, yang salah satunya adalah pengabdian pada masyarakat. Pelatihan ini ditujukan kepada ibu-ibu Rumah Tangga, adapun bentuk pelatihan berupa kiat dalam pemanfaatan barang-barang yang bernilai ekonomi bagi peningkatan produktivitas jiwa entrepreneur pada ibu rumah tangga. Dengan adanya kegiatan pelatihan ini akan dapat menciptakan kreativitas dan keterampilan ibu-ibu dalam pemanfaatan barang-barang bekas untuk menjadi barang yang bernilai ekonomi agar dapat meningkatkan pendapatan masyarakat di Desa Limbungan Kecamatan Rumbai Pesisir .

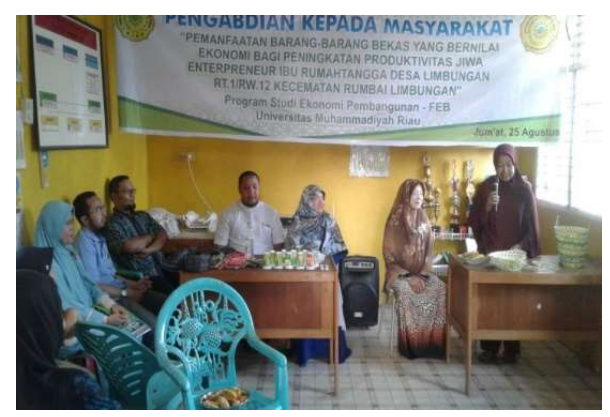

Gambar 2. Penyampain materi

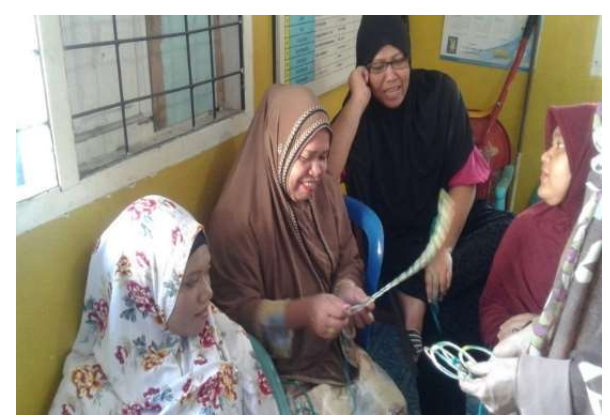

Gambar 3. Praktik membuat kerajinan tangan dari bahan bekas

Pada tahap pelaksanaan kegiatan ini dimulai dengan tahapan persiapan, tahapan persiapan dimana tim pelaksana kegiatan melakukan briefing untuk penyiapan bahanbahan yang dibutuhkan pada saat pelatihan, membagi tugas masing - 
ISSN : 2550-0198

masing pembicara, menyiapkan para peserta pelatihan, menyiapkan materi pelatihan yang berhubungan dengan pemanfaatan barang-barang bekas yang bernilai ekonomi.

Tahapan pelaksanaan kegiatan dilaksanakan sesuai dengan waktu yang telah di sepakati pada tanggal 25 Agustus 2017 bertempat di aula posyandu RT.01/RW.12 Desa limbungan Kecamatan Rumbai Pesisir. Tahapan pelaksanaan kegiatan dimulai dengan menjelaskan materi tentang Entrepreneur, manfaat dari berwirausaha, dan peluangpeluang usaha untuk memotivasi peserta dalam pemanfaatan barangbarang bekas yang bernilai ekonomi bagi peningkatan produktivitas jiwa entrepreneur. Tahapan pelaksanan selanjutnya yaitu demonstrasi pembuatan souvenir dari barang bekas sampai souvenir siap untuk dijual.

Tahapan pelatihan diberikan kepada setiap peserta berupa uraian atau langkah-langkah pembuatan produk dari, pembuatan produk dari botol bekas, pembuatan produk dari koran bekas, pembuatan produk dari plastik kemasan bekas. Arahan dan tanya jawab berlangsung pada saat kegiatan berlangsung, instruktur menjelaskan langkah-langkah pembuatan souvenir dari barang bekas yang berbahan kain perca, botol bekas, Koran bekas, plastic kemasan makanan bekas dan langsung mendemostrasikan kepada peserta. Peserta yang terbagi kedalam 3 kelompok mengikuti langkahlangkah yang diperagakan oleh instruktur sesuai dengan bahan dan alat yang digunakan. Pelatihan berlangsung mulai pukul 14.00 17.00 WIB.

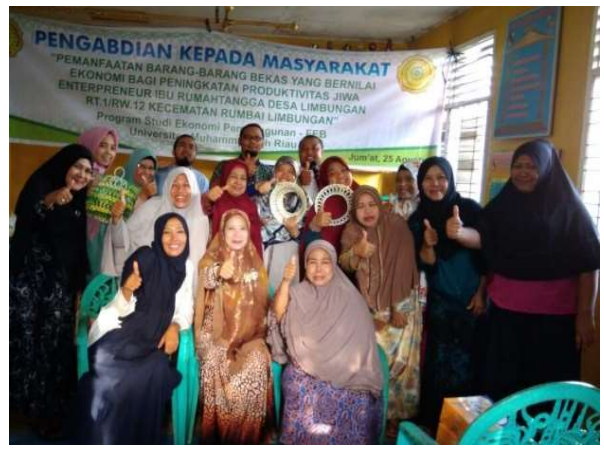

Gambar 4. Foto bersaama usai kegiatan

\section{SIMPULAN}

Secara keseluruhan kegiatan pelatihan pembuatan souvenir dengan pemanfaatan barang-barang bekas yang bernilai ekonomi berjalan baik dan lancar. Pelatihan ini memberikan keterampilan wirausaha kepada ibuibu Rumah Tangga di Desa Limbungan Kecamatan Rumbai Pesisir sebagai bekal wirausaha, atau pun sebagai bekal untuk memulai usaha sampingan. Materi kewirausahaan yang diberikan diharapkan dapat memotivasi peserta pelatihan untuk memulai usaha, dan diharapkan usaha tersebut dapat berjalan secara kontinue.

Pemahaman peserta pengabdian sebesar $80 \%$ memahami dan memiliki keterampilan dalam mempraktekan pembuatan souvenir dari pemanfaatan barang-barang bekas seperti kain perca, botol bekas, Koran bekas, selongsong bekas.

\section{UCAPAN TERIMAKASIH}

Terimakasih kami ucapkan kepada semua pihak yang mendukung kelancaran pengabdian ini terutama untuk Studio Riau, Pengusha muda Kota Pekanbaru dan kepada Bapak 
ISSN : 2550-0198

Ibu Dosen Universitas

Muhammadiyah Riau.

\section{DAFTAR PUSTAKA}

[1] A. Guruh Permadi. (2011). Menyulap Sampah Jadi Rupiah. Surabaya: Mumtaz Media.

[2] As'ad, M. 2002. Psikologi Industri. Yogyakarta: LIBERTY

[3] Achmad Serudji Hadi, Daur Ulang Barang Bekas sebagai Penopang Sumber Kehidupan, Laporan Penelitian pada Universitas Indonesia Program Pascasarjana Bidang Ilmu Hukum, Jakarta, 2001, h. 28-29

[4] Damanhuri, Enri \& Padmi, Tri. (2010). Pengelolaan Sampah. Retrieved from http://www.kuliah.ftsl.itb.ac.id/ wpcontent/uploads/2010/09/diktat sampah-2010-bag-1-3.pdf

[5] Departemen Pendidikan Nasional, Pusat Bahasa. 2008. Kamus Besar Bahasa Indonesia. Jakarta: Balai Pustaka.

[6] Faizah. (2008). Pengelolaan Sampah Rumah Tangga Berbasis Masyarakat (Studi Kasus di Kota Yogyakarta). Univesitas Diponogoro. Retrieved from http://eprints.undip.ac.id/17313 /1/faizah.pdf

[7] Gelbert M, Prihanto D, dan Suprihatin A, 1996. Konsep Pendidikan Lingkungan Hidup dan " Wall Chart ". Buku Panduan Pendidikan Lingkungan Hidup, PPPGT/VEDC, Malang
[8] Manik, K.E.S., 2003. Pengelolaan Lingkungan Hidup. Djambatan. Jakarta

[9] Machfoedz, Mas'ud. (2005). Kewirausahaan, Metode, Manajemen dan Implementasi. Yogyakarta: BPEE Yogyakarta.

[10] Prianto, Ragil, Agus. (2011). Partisipasi Masyarakat Dalam Pengelolaan Sampah Di Kelurahan Jombang Kota Semarang (Analisis Sosio Yuridis Pasal 28 Undang Undang No 18 Tahun 2008 Tentang Pengelolaan. Universitas Negeri Semarang. Retrieved from http://lib.unnes.ac.id/7974/1/85 61.pdf

[11] Purbasari,N. (2014). Pemberdayaan Masyarakat Melalui Kegiatan Daur Ulang Sampah Plastik (Studi Kasus Pada Komunitas Bank Sampah Poklili Perumahan Griya Lembah Depok Kecamatan Sukmajaya Kota Depok) Universitas Islam Negeri (UIN) Syarif Hidayatullah

[12] Slamet J,S, 2002. Kesehatan Lingkungan. Gadjah Mada Universty Press, Yogyakarta.

[13] Suryana. 2009. Kewirausahaan, Pedoman Praktis: Kiat dan Proses Menuju Sukses. Jakarta: Salemba Empat. 